
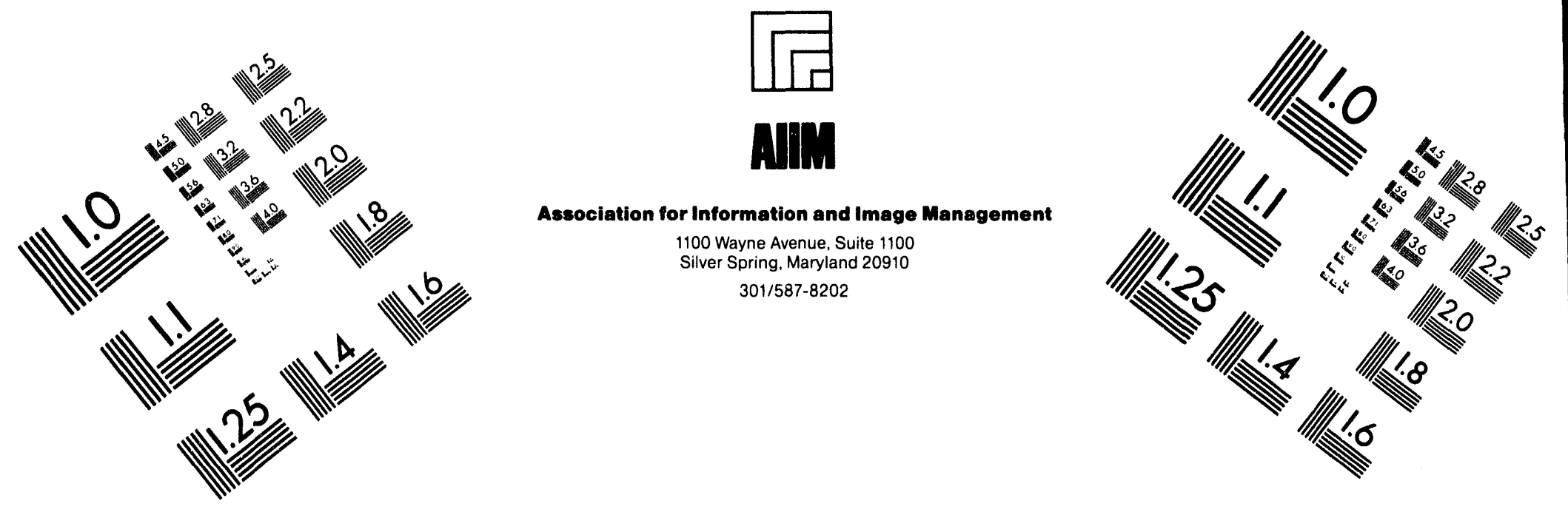

\title{
Centimeter
}

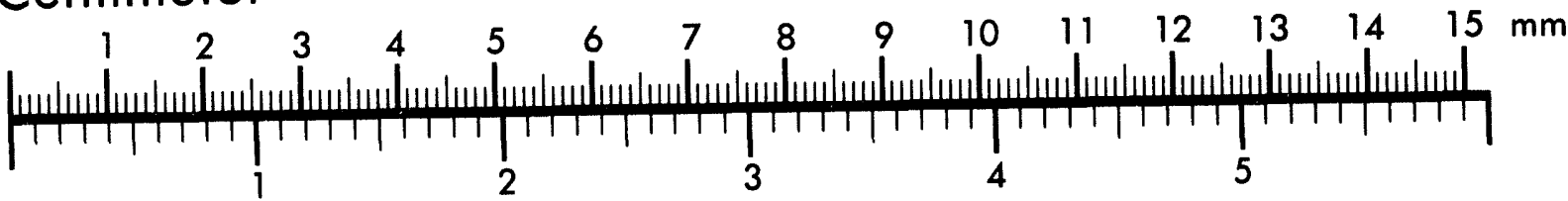
Inches
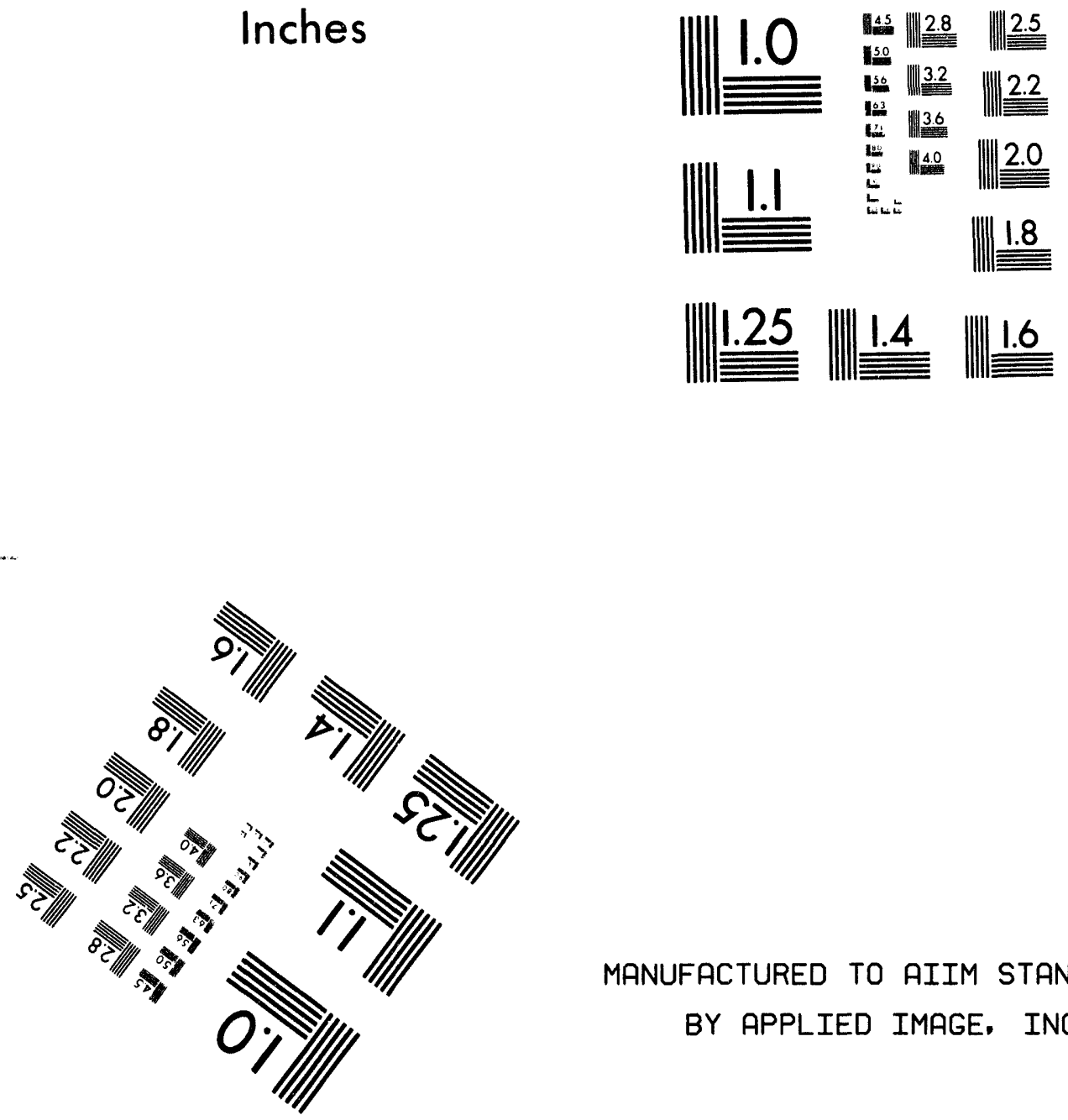

MANUFACTURED TO AIIM STANDARDS

BY APPLIED IMAGE, INC.

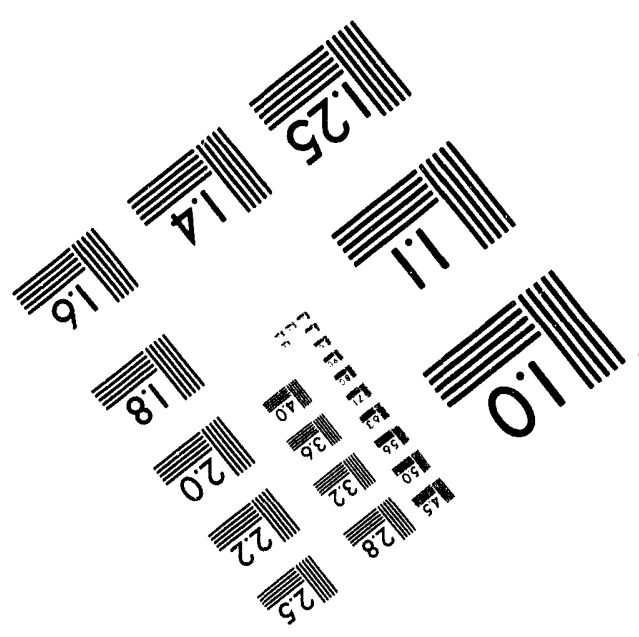



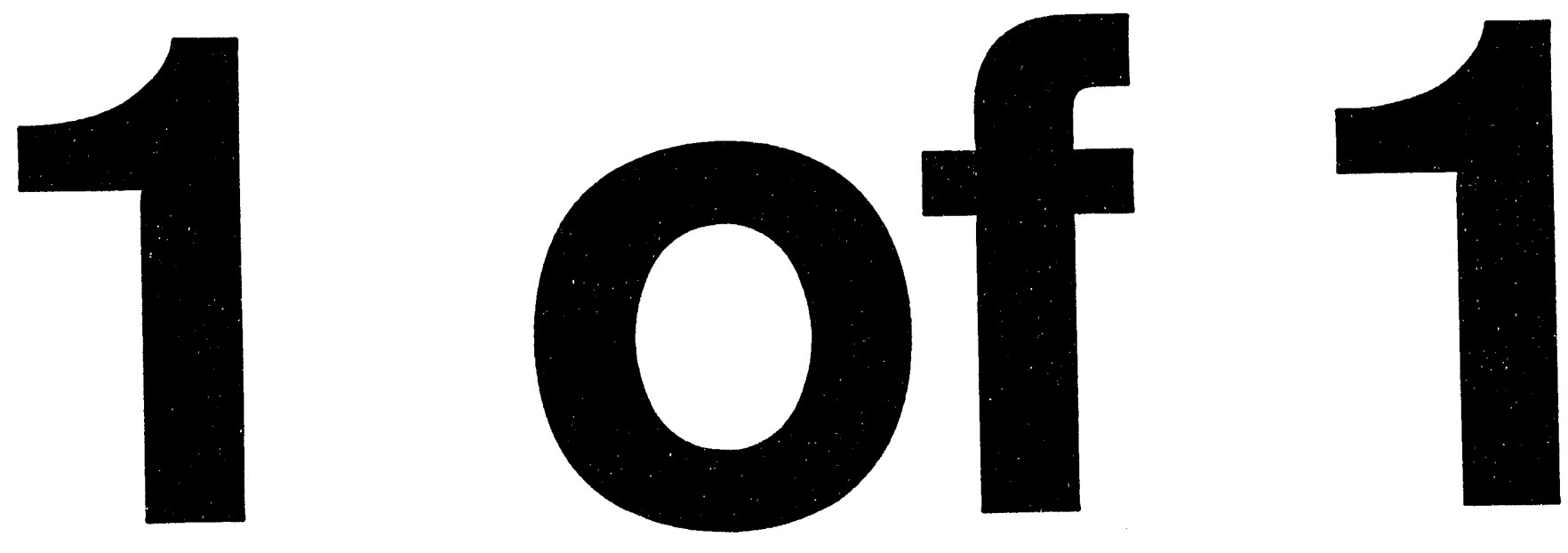


\section{Dose Assessment for Potential Radionuclide Emissions from Stacks on the Hanford Site: NESHAP Compliance}

W. E. Davis

J. M. Barnett

Westinghouse Hanford Company

J. L. Kenoyer

Science Applications

Intemational Corporation

Date Published

March 1994

To be Presented at

Federal Environmental Restoration III

\& Waste Minimization II Conference and Exhibition

New Orleans, Louisiana

April 27-29, 1994

Prepared for the U.S. Department of Energy

Office of Environmental Restoration and

Waste Management

Westinghouse
Hantord Company P.O. Box 1970

Hanford Operations and Engineering Contractor for the

U.S. Departinent of Energy under Contract DE-AC06-87RL10930

Copyright Llcenas By acceptance of this article, the publisher and/or recipient acknowledges the U.S. Government a right to retain a nonexclusive, royalty-tree licenses in and to any copyright covering this paper. 


\section{LEGAL DISCLAIMER}

This report was prepared as an account of work sponsored by an agency of the United States Government. Neither the United States Government nor any agency thereol, nor any of their employees, nor any of their contractors, subcontractors or their employees, makes any warranty, express or implied, of assumes any legal liability or responsibility for the accuracy, completeness, or any third party's use or the results of such use of any information, apparatus, product, or process disclosed, or represents that its use would not infringe privately owned rights. Relerence herein to any specific commercial product, process, or service by trade name, trademark, manufacturer, or otherwise, does not necessarily constitute or imply its endorsement, recommendation, or favoring by the United States Government or any agency thereof or its contractors or subcontractors. The views and opinions of authors expressed herein do not necessarily state or reflect those of the United States Government or any agency thereof.

This report has been reproduced from the best available copy.

Printod in the Unitod States of America 
Dose Assessment for Potential Radionuclide Emissions From

Stacks on the Hanford Site: NESHAP Compliance

W. E. Davis and J. M. Barnett

Westinghouse Hanford Company

J. L. Kenoyer

Science Applications International Corporation

\section{INTRODUCTION}

The Department of Energy Richland Operations Office,DOE RL, is a department, agency or instrumentality of the executive branch of the Federal Government and must comply with the requirements of the Clean Air Act (CAA) and its implementing regulations. On December 15, 1989, EPA promulgated in the Code of Federal Regulations (CFR) the National Emission Standards for Emissions of Radionuclides Other Than Radon From Department of Energy Facilities -- 40 CFR Part 61, Subpart $H$. Subpart $H$ requires the emissions of radionuclides from DOE facilities shall not exceed those amounts which would cause any member of the public to receive an effective dose equivalent (EDE) of $10 \mathrm{mrem}$ in a year. In addition, potential emissions of radionuclides from a facility which exceed $0.1 \mathrm{mrem} / \mathrm{yr}$ require continuous monitoring.

In order to determine compliance, section 61.93 provides requirements for monitoring of radionuclide emissions from point sources. These monitoring requirements became effective upon promulgation of the regulation on December 15, 1989. A1 so, DOE RL as defined in 40 CFR Part 61 is an "owner or operator" of a "facility", i.e. the Hanford Site. Some monitoring systems on the Hanford Site which meet the continuous monitoring requirement do-not use EPA approved methods as specified in the regulations. A preliminary assessment performed in 1991 of the registered stacks, i.e., registered with the Washington State Department of Health, revealed that 7 stacks would require continuous monitoring. On May 7, 1991 DOE RL requested approval of the existing measurement systems for these stacks. On June 03, 1991 EPA denied approval of these systems.

On February 3, 1993, the U.S. Department of Energy, Richland Operations Oifice (RL) received a Compliance Order and Information Request from the Director of the Air and Toxics Division of the U.S. Environmental Protection Agency (EPA), Region 10. The Compliance Order requires RL to evaluate all radionuclide emission points at the Hanford Site $t$. determine which are subject to continuous emission measurement requirements in 40 CFR Part 61, Subpart H, and to continuously measure radionuclide emissions in accordance with 40 CFR 61.93. The Information Request required RL to provide a written Compliance Plan to meet the requirements of the Compliance Order. A Compliance Plan was submitted to EPA, Region 10, on April 30, 1993.

The Compliance Plan set as one of the milestones: Complete assessment of the 84 Hanford Site registered stacks under management by WHC by December 17, 1993. 
The purpose of this document is to present the assessment results for the registered stacks on the Hanford Site for potential emissions, 1. e. emissions with no control devices in place. Further, the document will identify those stacks requiring continuous monitoring, $i$. e. the effective dose equivalent from potential emissions $>0.1 \mathrm{mrem} / \mathrm{yr}$.

\section{SCOPE}

The stack assessment of potential emissions was performed on 84 registered stacks on the Hanford Site. These emission sources represent individual point sources presently registered under Washington Administrative Code 246-247 with the Washington Department of Health. The methods used in assessing the potential emissions from the stacks are described below.

\section{METHODS FOR CALCULATING POTENTIAL STACK EMISSIONS}

The calculation of potential emissions for the :egistered stacks were made using five methods approved for use by U.S. Environmental Protection Agency, Region 10:

1. Source Term Estimation Based on release factors in Appendix D

2. Back Calculations Based on a Decontamination Factor of $3000^{n}$, where $n$ equals the number of HEPA filter banks in series

3. Nondestructive Assessment (NDA)

4. Upstream of HEPA Filter Air Concentration Measurements

5. Spill Release Fraction (296-A-5)

Calculations based on the first two methods are considered extremely conservative. The last three methods shouid provide a realistic estimate of the actual potential releases. When the assessment of stack emissions based on Appendix $D$ or from back calculations could indicate that the potential emissions would result in an Effective Dose Equivalent, EDE, exceeding 0.1 $\mathrm{mrem} / \mathrm{yr}$, while one of the last methods would result in an EDE less than 0.1 $\mathrm{mrem} / \mathrm{yr}$, this more realistic method results would be accepted over the first two conservative methods.

\section{A. Appendix D Release Factors}

The potential emissions for a system without control devices can be estimated based on factors presented in 40 CFR 61 Appendix D: for gases the release factor is 1 , for liquids or particulate solids the release factor is $1 \times 10^{-3}$, and for solids the release factor is $1 \times 10^{-6}$. This method is extremely conservative, since accidents involving liquids and loose particulates have a release fraction orders of magnitude less than the $1 \times 10^{-3}$ release fraction. In an accident condition, a spill of powder from a one meter height of the entire inventory would release under extremely conservative conditions $4 \times 10^{-5}$ release fraction and a 1 iquid spill from the same would release approximately $1 \times 10^{-6}$ release fraction. A $1 \times 10^{-3}$ release fraction is used for powders and liquids In cases where the assessment was performed on waste tanks, if the 
inventory was covered by supernate the supernate was evaluated using the release factor for liquids while the covered salt cake was estimated using a release factor for solids.

\section{B. Back Calculations Based on a Decontamination Factor of $3000^{n}$}

This method for estimating potential emissions assumes the Nuclear Air Cleaning Handbook (1976) decontamination factor (DF) of 3000 (DF $1 /(1-$ $0.9997)$ ) for a HEPA filter. The method assumes that each bank in series acts independently of a preceding bank and will remove contamination with the same 3000 decontamination factor. For a system with $n$ banks of HEPA filters in series, the decontamination factor is $3000^{n}$. This method can be conservative for a contaminated systeni. When processing no longer occurs, the resuspension of contamination downstream of the HEPA filters can dominate the airborne releases from a facility. Multiplying these releases by $3000^{n}$ will overestimate the potential emissions by orders of magnitude.

\section{Nondestructive Assessment (NDA)}

In September 1992, the U.S. Environmental Protection Agency (EPA), Region 10, concurred with a Westinghouse Hanford Company proposal for a test method to measure radioactive particulate emissions (particularly gamma emitters from high-efficiency particulate air (HEPA) filters) in stack exhauster systems across the Hanford Site. A nondestructive assessment (i.e., in situ) method was developed, tested, and implemented using portable low-resolution ( $\mathrm{NaI}$ ) gamma spectroscopy instrumentation to evaluate gamma emissions from operating HEPA filters. Guidance for the developed method comes from the 40 CFR 61 , Subpart $H$ and Appendix B, Method 114.

In the laboratory, the spectrometer is energy calibrated using the two peaks obtained from a ${ }^{22} \mathrm{Na}$ check source $\mathrm{placed}$ into a representative HEPA filter geometry. For all measurements of the same geometry, the detector head is placed up flush against the HEPA filter system at the center of the vertical side to assure replicate sampling. After the energy calibration, regions of interest are established for the given HEPA filter geometry using certified gamma check sources for the expected in-field conditions. Typical isotopes seen in the field include ${ }^{54} \mathrm{Mn},{ }^{60} \mathrm{Co}$, and ${ }^{137} \mathrm{Cs}$. For ${ }^{137} \mathrm{Cs}$, the intrinsic efficiency is in the range of 11 to 16 percent, and its region of interest resolution is 8.5 percent. In-field background measurements are collected before actual sampling of the HEPA filters begins. Typically, the minimum detectable activity is on the order of $100 \mathrm{nCi}$ (Altschuler and Pasternack 1963). The efficiency and minimum detectable activity are given by the following equations: 


$$
\eta=\frac{c p m}{d p m} \times 100=\frac{\left[\frac{\text { counts }}{t(1-D T)}\right]_{\text {source }}-\left[\frac{\text { counts }}{t(1-D T)}\right]_{\text {background }}}{A_{0} e^{-\lambda \Delta t}} \times 100=8
$$

where:

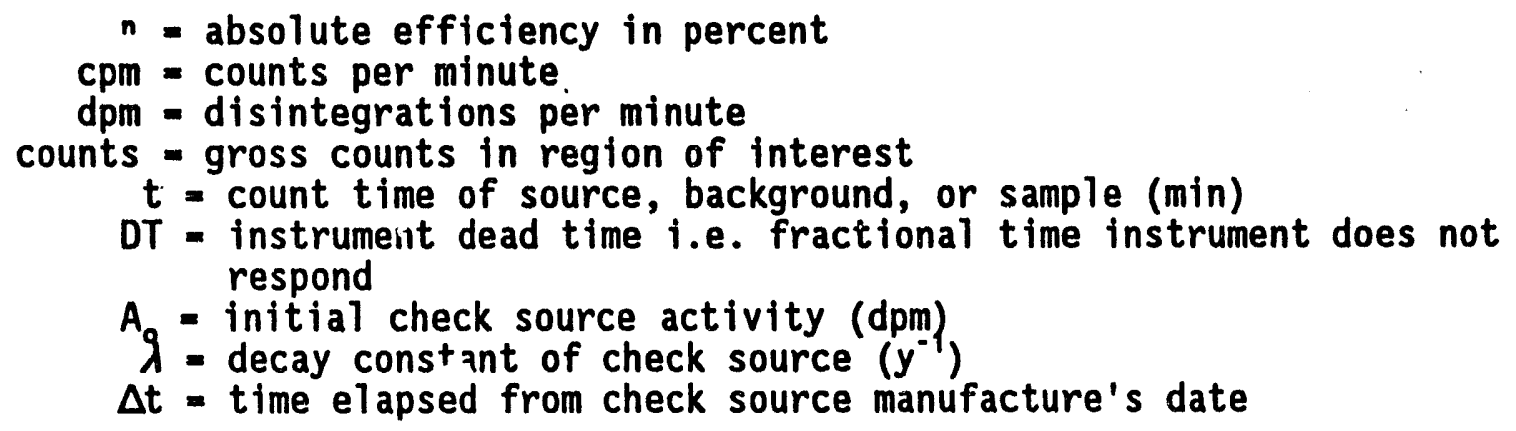

$n=$ absolute efficiency in percent

$\mathrm{cpm}=$ counts per minute

$\mathrm{dpm}=$ disintegrations per minute

counts = gross counts in region of interest

$t$ = count time of source, background, or sample (min)

DT = instrumeit dead time i.e. fractional time instrument does not respond

$A_{0}=$ initial check source activity (dpm)

$\lambda=$ decay constant of check source $\left(y^{-1}\right)$

$\Delta t=$ time elapsed from check source manufacture's date

$$
M D A=\frac{4.66 \sqrt{\left[\frac{\text { counts }}{t^{2}(1-D T)}\right]_{\text {background }}}}{2.22 \eta}=p C i
$$

where:

MDA = Minimum detectable activity

4.66 = the value used to determine the instrument reading with a difference from background that is large enough to be statistically significant at the $99 \%$ confidence level

2.22 = the conversion from counts per minute to picocuries.

In the field, HEPA filters are assessed, the data are logged, the resultant spectra are electronically saved and the instrument dead time noted. Stacks which have excessive instrument dead time (i.e., >40\%) can not be assessed using this method. HEPA filter data are decay corrected and average annual potential emissions are determined for each gamma emitting isotope. Additionally, activity estimates are made for a]pha and beta emitters from ratios derived from reported emissions. Summing the reported annual isotopic emissions and the derived average annual emissions from the HEPA filters results in the annual total potential emissions. Equations for the HEPA filter activity and the potential resultant dose are given below. 


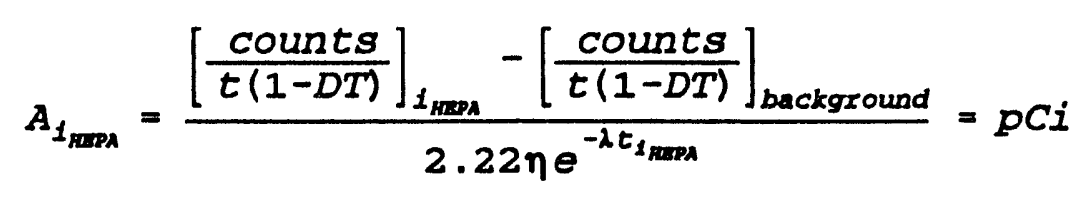

where:

$\begin{aligned} A_{\text {IHEPA }} & =\text { activity of } i \text { th HEPA filter ( } P C i \text { ) } \\ t_{\text {iHEPA }} & =\text { time elapsed from HEPA filter installation to measurement } \\ \text { date }(y) . & \end{aligned}$

\section{Upstream of HEPA Filter Air Concentration Measurements}

The upstream air concentrations provide direct information on the potential emissions from a facility. This method can be applied by using Continuous Air Monitoring (CAM) data, inserting an air sample probes for upstream measurements, or radiological analysis of removed HEPA filters. CAM data can be used if the data is taken from the process area which contains the radionuclide inventory. Air measurements may also be collected in the ventilation system upstream of the HEPA filters. In this case, a sampling port is selected, a probe inserted, and air concentrations are measured. The final method is the sampling of the furthest upstream HEPA filters for the facility. In this case one or more HEPA filters are removed and the radiological content is analyzed either by destructive assay or by a gamma spectrometer. The airflow during the time the HEPA filter is online is used to determine the annual release rate. All of these methods are technically based in that the measurements represent the potential concentrations emitted from a facility without control devices.

\section{E. Spil1 Release Fraction (296-Z-5)}

In the facility venting to the $296-Z-5$ stack, the only potential emissions occur when a canister of $\mathrm{PuO}_{2}$ powder is repackaged. No emissions are expected from contamination in the ventilation system for the facility since it is essentially uncontaminated. When a canister is to be repackaged, the double canisters containing 1500 grams of $\mathrm{PuO}_{2}$ are opened in a hood and the powder is poured into another canister. The canister is sealed and put into another canister and it is sealed. The pouring could cause a release $\mathrm{PuO}_{2}$ to the air. To estimate the potential maximum release, observed spil1 release fractions for depleted uranium oxide spills (Sutter et al, 1981) was used. A maximum release fraction value of $4.0 \times 10^{-5}$ was used. This number is extremely conservative since it represents a release fraction for a 1 meter release height for the spill. The actual release height is a maximum of 0.15 meters. The spill release fraction was only used for the 296-Z-5 stack.

\section{CAP88 DOSE MODELING}


A potential source term was calculated for the 84 registered stacks using one of the five approved methods. Once the potential source terms were determined, the source term, location, and stack height were used with Hanford meteorology in the CAP88 computer model (Beres, 1991) to predict the effective dose equivalent for the maximum exposed individual.

The CAP88 model is able to incorporate plume rise from the stack based on the flow rate and stack diameter. After leaving the stack, the plume is modeled to disperses based on meteorological conditions. Modeled concentrations are decreased based on dry deposition (dry deposition velocity $=1.8 \mathrm{~cm} / \mathrm{s}$. ) However, wet deposition is ignored because of the low incident of precipitation on the Hanford Site. The modeled concentrations are used to calculate an Effective Dose Equivalent for an offsite maximum exposed individual (MEI) by summing the product of the EDE for each isotope with its activity.

$$
\dot{H}_{\text {total }}=\Sigma\left(E D E_{(1)} \times A_{(1)}\right)=\text { mrem } y^{-1}
$$

where:

$$
\begin{aligned}
& \dot{H}=\text { potential unabated dose to the MEI } \\
& E D E_{(i)}=\text { effective dose equivalent for each radionuclide. }
\end{aligned}
$$

Normalized source terms were used in CAP88 for each of the major areas on site, i.e., $100,200,300,400$, and 600 areas. Five year averaged Hanford meteorological data (1983-1987) taken on the site was used to compute normalized air concentrations, i.e, $X / Q$, where $X$ is the air concentration (curies $/ \mathrm{m}^{3}$ ) normalized by the source term $Q$ (curies/s.) Two stack release heights were used: 89 meters (200 ft stack بth a $100 \mathrm{ft}$ plume rise) and 10 meters (33 ft.) To model an individual stack. the following input was needed: the potential radiological source terms, the stack release height was chosen, and the location of the stack in one of the major areas. Potential dose data was produced by the CAP88 model for each registered stack. 


\section{RESULTS OF DOSE ASSESSMENT}

Of the 84 stacks assessed, 41 were assessed using release fractions from Appendix D, 32 using back calculations, nine stacks using NDA, two using upstream air samples, and one was assessed using the powder release fraction. 15 stacks (see Table 1) were identified to have potential emissions which could cause an effective dose equivalent $>0.1 \mathrm{mrem} / \mathrm{y}^{\mathrm{r}}$.

Table 1

Designated Stacks ${ }^{1}$

\begin{tabular}{||l|l|c|}
\hline \multicolumn{1}{|c|}{ Stack Number } & \multicolumn{1}{|c|}{ Facility } & Number of HEPA Filters \\
\hline $291-A-1^{2}$ & PUREX & \multicolumn{1}{|c|}{3} \\
\hline $296-A-1$ & PUREX & 3 \\
\hline $291-B-1^{2}$ & B PLANT & 2 \\
\hline $291-Z-1^{2}$ & PFP & $1-3$ \\
\hline $296-Z-3$ & PFP & 2 \\
\hline $296-A-22$ & TANK FARMS & 2 \\
\hline $296-A-27$ & TANK FARMS & 2 \\
\hline $296-A-29$ & TANK FARMS & 2 \\
\hline $296-A-40^{2}$ & TANK FARMS & 2 \\
\hline $296-P-16$ & TANK FARMS & 2 \\
\hline $296-A-22^{2}$ & TANK FARMS & 2 \\
\hline $296-P-23$ & TANK FARMS & 2 \\
\hline $296-S-7 W$ & ERO & 2 \\
\hline $296-S-15$ & TANK FARMS & 2 \\
\hline $308-G L-E X$ & 308 BUILDING & 3 \\
\hline $340-N T-E X^{2}$ & 340 BUILDING & 2 \\
\hline
\end{tabular}

To compare the effects of using the five different methods, these methods were compared to the result of using back calculations for all stacks. The back calculations indicated emissions from 32 stacks would have caused an EDE which would have exceeded $0.1 \mathrm{mrem} / \mathrm{yr}$ and required the stacks to provide continuous monitoring. A comparison made for 30 stacks using release factors from Appendix $D$ with back calculations showed no correlation between the two

1 Stacks with the potential to exceed $0.1 \mathrm{mrem} / \mathrm{yr}$

2 Original Seven Designated Stacks 
methods (Figure 1.) The comparison between NDA and back calculations showed that back calculations over estimated the potential releases for all nine stacks by at least 4 orders of magnitude (Figure 2.) If back calculations had been used instead of NDA, all nine of these stacks would have required continuous monitoring. Upstream air sample method for two of the stacks showed that the back calculations overestimated the emissions by three orders of magnitude. For the single stick that used the powder release fraction, the back calculations overestimated the release by four orders of magnitude.

\section{CONCLUSIONS}

By using the five approved methods approved by EPA, Region 10 instead of only the back calculation method for assessing the 84 WHC stacks, the number of stacks requiring continuous monitoring was reduced from 32 to the 15 .

The comparison between results using the back calculation with the results using the other methods showed that no correlation existed between back calculations and the results using release fractions from Appendix $D$. When the NDA, upstream air samples, and powder release fraction methods were compared to back calculations, the effective dose equivalents from the back calculations were at least three orders of magnitude higher.

The most exciting result of the assessment was the application of NDA. NDA when applied was found to be an easy method for assessing potential emissions. For the nine stacks where NDA was applied, all nine of the stacks would have required continuous monitoring when using back calculations. However, when NDA was applied all stacks had potential emissions that would cause an effective dose equivalent below the $0.01 \mathrm{mrem} / \mathrm{yr}$ standard.

\section{REFERENCES}

40 CFR 61, Subpart H, National Emission Standards for Emissions of Radionuclides other than Radon from Department of Energy Facilities, "National Emission Standards for Hazardous Air Pollutants, "Code of Federal Regulations, as amended.

40 CFR 61, Appendix B, Method 114, Test Methods for Measuring Radionuclide Emissions from Stationary Sources, "National Emission Standards for Hazardous Air Pollutants," Code of Federal Regulations, as amended.

Altschuler, B., and B Pasternack, 1963, "Statistical Measures of the Lower Limit of Detection of a Radioactivity Counter, Health Phys., Vol. 9,. p. 293.

Barnett, J. M., 1994, "In Situ Measurement of Gamma Radiation from High-Efficiency Particulate Air Filters Using Portable Low-Resolution Gamma Spectrometry" WHC-SA-2272-FP, Westinghouse Hanford Company, Richland WA 99352

Beres, D. A., 1990, The Clean Air Act Assessment Package - 1988 (CAP-88). A Dose and Risk Assessment Methodology of Radionuclide Emissions to Air, Vols. 1-3, U.S. Environmental Protection Agency, Washington,

BTI Portable Gamma-Ray Spectrometer Microspec-1 IM with Gamma-Ray Probe, 1991, Bubble Technology Industries, Inc., Chalk River, Ontario, Canada 
Buchsted, C. A., A. B. Fuller, and J. E. Kahn, 1976 "Nuclear Air Cleaning Handbook" ERDA 76-21, UC-11, 70 Oak Ridge National Laboratory, Oak Ridge TN 37830

Environmental Assurance, 1991 "Unit Dose Calculation Methods and Summary of Facility Effluent Monitoring Plan Determinations" WHC-EP-0498, Westinghouse Hanford Company, Richland, WA 99352

Mizner, J. H. Jr., and J. M. Barnett, 1993, "The 291-T-1 Exhaust Stack Petition for Redesignation" WHC-SD-WM-ER-292, Westinghouse Hanford Company, Richland WA 99352

Sutter, S. L., J. W. Johnson, and Jofu Mishima, 1981 "Aerosols Generated by Free Fall of Powders and Solutions in Static Airn NUREG/CR-2139, PNL-3786 RH 


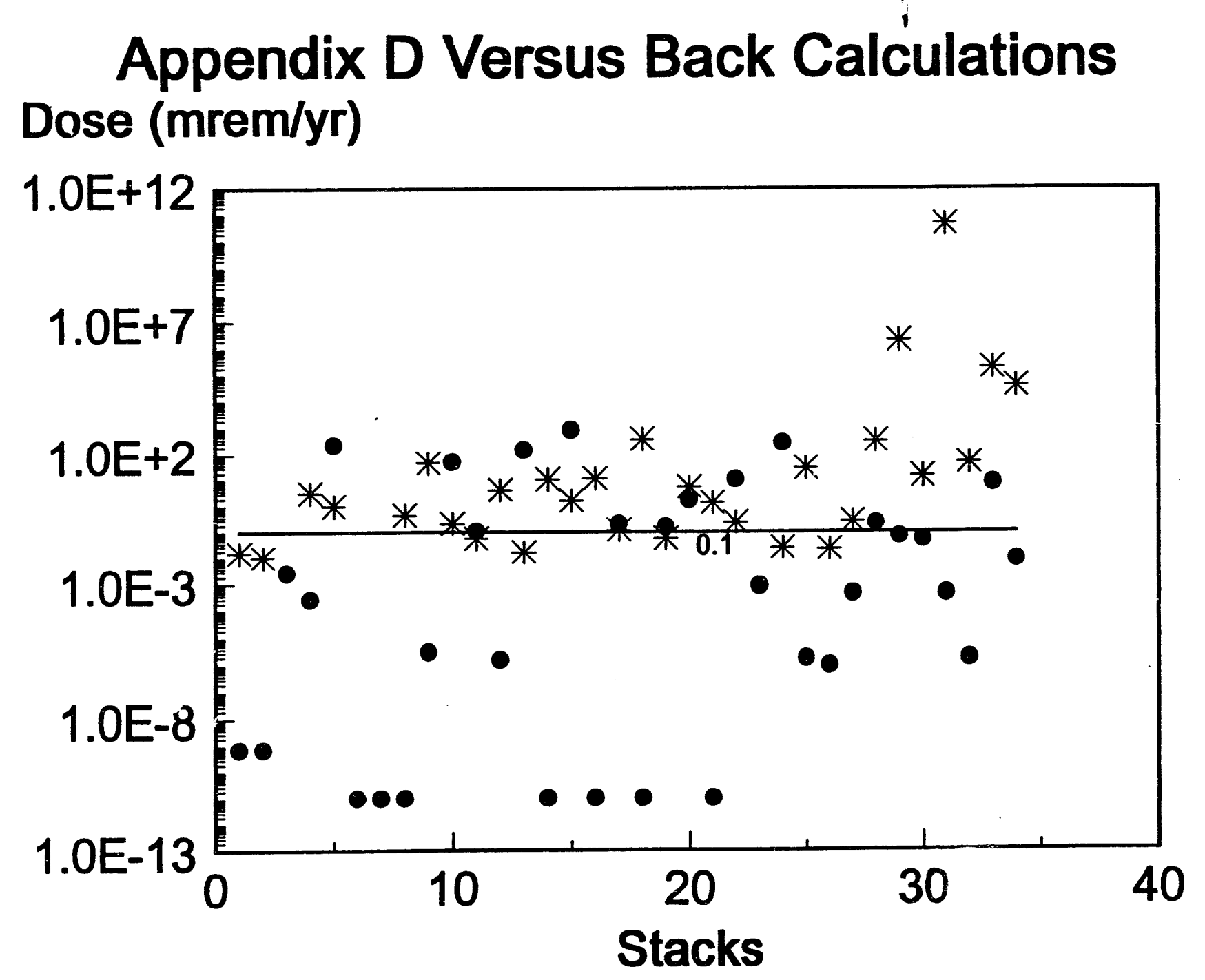




\section{Appendix D Versus Back Calculations}

Dose (mrem/yr)

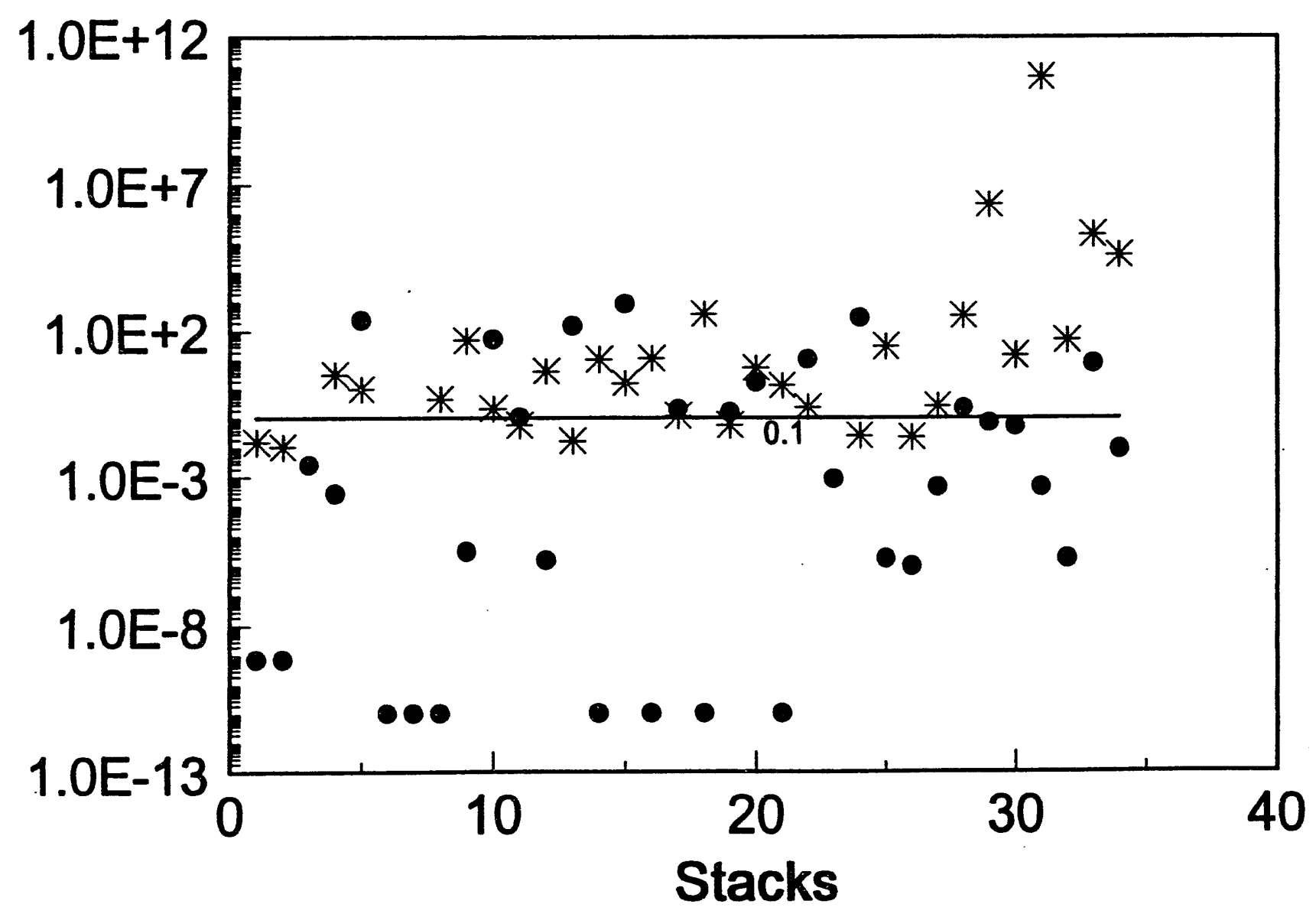


Figure 2 Comparison of NDA With Back Calculations mrem/yr

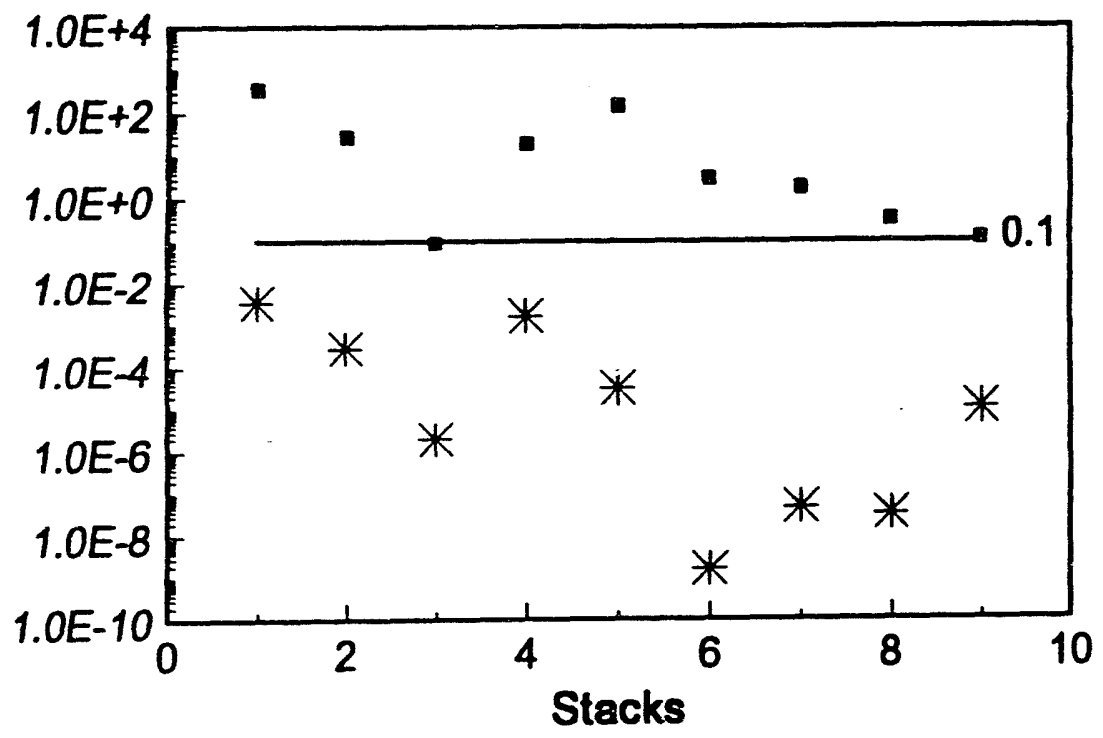



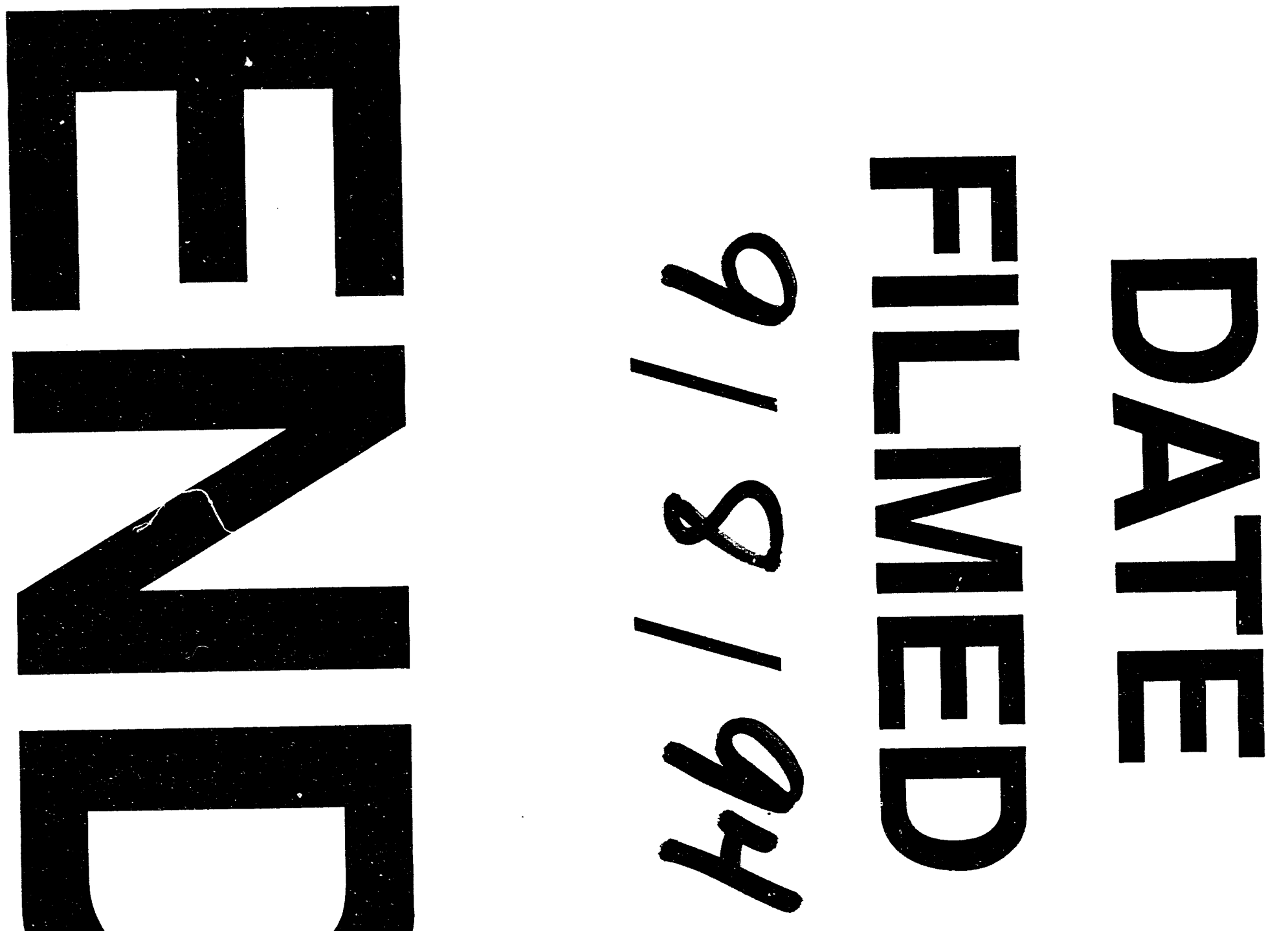
